Vol. 8, Issue 8, August 2021

DOI: $10.17148 /$ IARJSET.2021.8835

\title{
A Study on Stress and Alcohol Consumption of College Students
}

\author{
Dr. B. Nalatha Vijilin', Dr. J. Ethen Malar² \\ ${ }^{1}$ Assistant Professor, Department of Commerce, Scott Christian College (Autonomous), Nagercoil. \\ ${ }^{2}$ Associate Professor, Department of Commerce (Accounting \& Finance), Women's Christian College (Autonomous), \\ Chennai.
}

\section{INTRODUCTION:}

Stress and depression are the major problems at present in the minds of college students. This study was conducted to know the level of stress and alcohol consumption of college students due to the closure of colleges and online teaching in Kanyakumari District. Hundred respondents opined about their stress and the consumption of alcohol. Due to the pandemic situation around the world schools and colleges were closed during the month of March 2020. Colleges started running their activities through digital mode. It leads to stress among teachers, parents, and students. Teachers were forced to run behind a new digital mode of teaching. Due to a lack of awareness about new technologies teachers suffered a lot during the beginning of this pandemic situation. Even now the situation is worse in our district due to the lack of proper net connections in remote areas.

The recent statistics of NIAAA estimate that about 1,519 college students age between 18 to 24 die from alcohol-related unintentional injuries. 97,000 students age between 18 to 24 experiencing alcohol-related sexual assault. Continuous usage of alcohol leads to permanent brain damage. Madras high court on April 222018 stated that the students will not enter into college in inebriated conditions. The judge also expressed "The student phase should be a knowledge gaining phase and the knowledge gained in the process would empower the person to lead a better life by getting appropriate posting and thereby leading a decent life".

\section{Statement of the Problem:}

Alcohol usages during college years roughly reach 80 percent of college students (ie. Four out of five). Out of this 50 percent of those students are in binge drinking. Frequent heavy drinking increases the chance of alcohol use disorder. This leads to severe physical and emotional problems. Alcohol use of college students is actually a public health concern. It leads to academic decline, psychological distress, suicide, accidents, and risky sexual behaviour. This drinking habit affects their academics and they started to give priority over attending classes, completing homework, and studying for exams. Closure of colleges due to Covid-19 increased the stress level of students and many are addicted to alcohol at present. This study identifies the problems and how it affects the students' life.

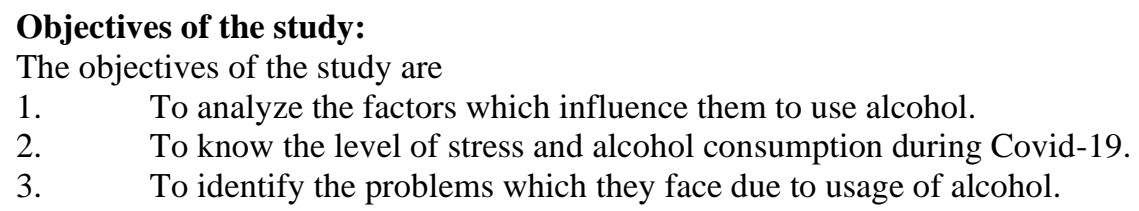

\section{REVIEW OF LITERATURE:}

KARF (2011) Korea is one of the countries with a high rate of prevalence of alcohol consumption among college students. According to a report of the Korean Alcohol Research Foundation (KARF) in 2010, 85.4\% of college students experienced drinking during the past month.

White and Hingson (2014) In general, excessive alcohol consumption leads to various negative consequences on body functions. For example, it causes impairments in cognitive functions, including poor decision-making and impulsiveness.

Nichols et.al (2012) Excessive alcohol consumption is one of the most well-known risk factors of various chronic diseases and conditions, such as liver cirrhosis, cancer, and a fetal alcohol spectrum disorder.

Sacks et.al.(2013) In addition to the effects on body functions, excessive alcohol consumption is closely related to adverse social consequences including increased health care costs, unintentional injuries, and violence, increased crime, and reduced work productivity. 
Vol. 8, Issue 8, August 2021

\section{DOI: 10.17148/IARJSET.2021.8835}

\section{METHODOLOGY:}

Primary and secondary data were collected. The researcher has adopted a stratified proportionate random sampling method to select the respondents. The respondents are from Scott Christian College, Nagercoil. The number of respondents taken as sample respondents for the study is limited to 100. Statistical tools like the weighted average method, Garrett's ranking, and Likert's attitude scaling method were used.

Age wise distribution of respondents:

\section{ANALYSIS AND INTERPRETATION:}

The following table shows the age wise distribution of college students.

\begin{tabular}{|c|c|c|c|}
\hline S.No. & Age & Respondents & Percentage \\
\hline 1 & $17-19$ & 60 & 60 \\
\hline 2 & $20-22$ & 30 & 30 \\
\hline 3 & $23-25$ & 10 & 10 \\
\hline \multicolumn{2}{|c|}{ Total } & 100 & 100 \\
\hline
\end{tabular}

The above table inferred that majority of the students are from the age group of 17-19, 30 percent of the respondents from the age group of 20-22 and 10 percent from the age of 23-25.

Factors influencing to use alcohol:

In Colleges, many factors normally influence the students to use alcohol. Some of the factors were analysed with the help of weighted average method.

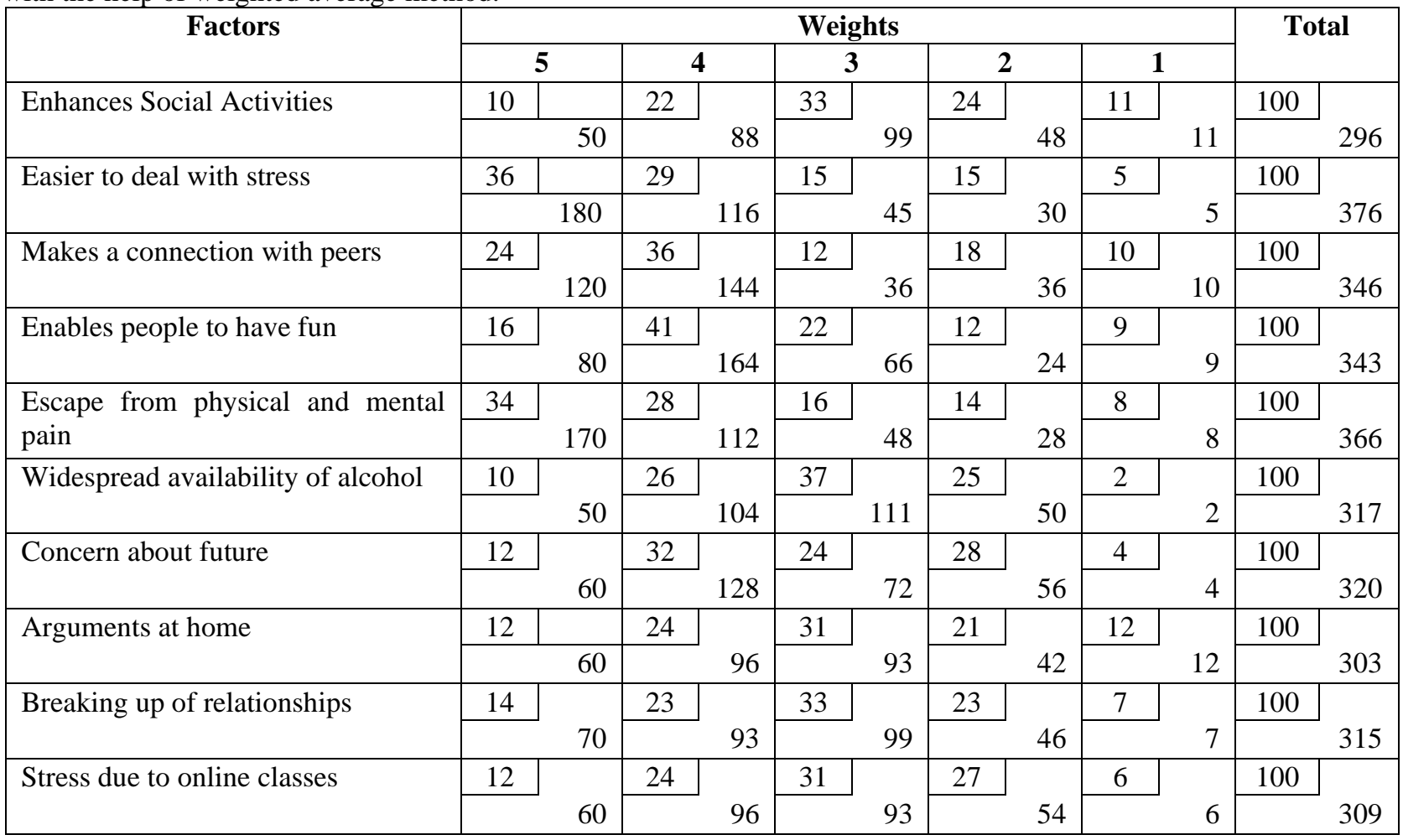

\begin{tabular}{|c|l|c|c|}
\hline \multicolumn{1}{|c|}{ Factors } & Weighted Average Rank & Rank \\
\hline S.No. & \multicolumn{1}{|c|}{ Weighted Mean } & X \\
\hline 1 & Enhances Social Activities & 2.96 & I \\
\hline 2 & Easier to deal with stress & 3.76 & III \\
\hline 3 & Makes a connection with peers & 3.46 & IV \\
\hline 4 & Enables people to have fun & 3.43 & II \\
\hline 5 & Escape from physical and mental pain & 3.66 & VI \\
\hline 6 & Widespread availability of alcohol & 3.17 & V \\
\hline 7 & Concern about future & 3.20 & IX \\
\hline 8 & Arguments at home & 3.03 & VII \\
\hline 9 & Breaking up of relationships & 3.15 & VIII \\
\hline 10 & Stress due to online classes & 3.09 & \\
\hline
\end{tabular}




\title{
International Advanced Research Journal in Science, Engineering and Technology
}

\author{
Vol. 8, Issue 8, August 2021
}

\section{DOI: $10.17148 / I A R J S E T .2021 .8835$}

It can be inferred from the above table that, the major factor which influence to take alcohol is 'Easier to deal with stress' ranks first with a mean score of 3.76, 'Escape from physical and mental pain' ranks second with a mean score of 3.66, 'Makes a connection with peers' ranks third with a mean score of 3.46, enables people to have fun, concern about future, widespread availability of alcohol ranks fourth, fifth and sixth respectively.

\section{Level of Stress:}

Due to the Pandemic situation colleges have been closed from March 2020 onwards and it created lots of tension in the minds of students. Mainly being at home, attending classes online, new technologies to proceed further education, loneliness, and family situation leads to depression and stress. Most of the students to reduce stress started consuming more amount of alcohol. So there is a need arise to find out the level of stress using Likert's attitude scaling technique.

\begin{tabular}{|c|l|c|c|c|}
\hline S.No. & \multicolumn{1}{|c|}{ Attitude } & Total Score & Mean & Level \\
\hline 1 & Family situation & 422 & 4.22 & Highly influential \\
\hline 2 & Online education & 278 & 2.78 & Neutral \\
\hline 3 & Loneliness & 352 & 3.52 & Influential \\
\hline 4 & Parents expectation & 270 & 2.70 & Neutral \\
\hline 5 & Concern about future & 346 & 3.46 & Influential \\
\hline
\end{tabular}

The mean score for a family situation from the data is 4.22 . As the mean score for the factor falls within the range of $4.21-5$ the level of attitude is highly influential.

The mean score for Loneliness and Concern about the future is 3.52 and 3.46. As the mean score for the factor falls within the range of 3.41-4.20 the level of attitude is influential.

The mean score for Online education and Parents' expectation is 2.78 and 2.70. As the mean score falls within the range of 2.61-3.40 the level of attitude is neutral.

\section{Problems due to usage of alcohol:}

The problem due to usage of alcohol is identified and using Garrett's Ranking Technique it has been ranked according to priority. The respondents were given the reason and asked to rank them according to the choice. The order of rank given by the respondents was converted into ranks.

\begin{tabular}{|c|l|c|c|}
\hline S.No. & \multicolumn{1}{|c|}{ Problems } & $\begin{array}{c}\text { Garrett's } \\
\text { Mean } \\
\text { Score }\end{array}$ & Rank \\
\hline 1 & Interrupts studying & 56.27 & I \\
\hline 2 & Makes feel unsafe & 39.58 & VII \\
\hline 3 & Become violent and aggravated & 55.62 & II \\
\hline 4 & Unwanted sexual experiences & 43.79 & VI \\
\hline 5 & Health problems and injuries & 55.48 & III \\
\hline 6 & Wastage of money & 50.16 & IV \\
\hline 7 & Guilty feeling & 49.40 & V \\
\hline
\end{tabular}

The above table clearly shows the problems faced by the college students due to the usage of alcohol. 'Interrupts studying' ranks first with a mean score of 56.27, 'Become violent and aggravated ranks second with a mean score of 55.62, 'Health problems and injuries' ranks third with a mean score of 55.48 and 'Wastage of money' ranks fourth with a mean score of 50.16. Guilty feeling, unwanted sexual experiences, and makes feel unsafe ranks fifth, sixth, and seventh respectively

\section{SUGGESTIONS:}

It is not easy to quit drinking or reduce drinking alcohol and for many people, it will be a lifelong struggle. This drinking habit again increased a lot in this pandemic situation due to stress. So to reduce the stress they can practice the following i) Do not keep alcohol at home. ii) Do not skip meals iii) Do start exercise iv) Do recognize the wonderful miracle of pure drinking water and v) Distance yourself from people who do not support your effort.

Government should take some steps to reduce the drinking habits of college students. The suggestions are

- $\quad$ Changing cultural misconceptions and behaviours about alcohol use through education.

- $\quad$ Non-availability of alcohol to young people under age 21.

- $\quad$ Proper enforcement of existing laws and regulations regarding alcohol purchase. Ignorance of law not only enables young people to drink but also communicates a general indifference to underage drinking.

- $\quad$ Proper access to treatment and recovery support services for adolescents and their families

- Government should stop the supply of alcohol through Tasmac. 


\section{International Advanced Research Journal in Science, Engineering and Technology}

Vol. 8, Issue 8, August 2021

\section{DOI: 10.17148/IARJSET.2021.8835}

\section{CONCLUSION:}

Youngsters are the real assets of our country. Future financial and economic development is in the hands of youngsters. We must safeguard the life of college students.

\section{REFERENCES:}

1. Korean Alcohol Research Foundation (KARF) (2011) Comparison studied on college students and adult in drinking behaviour.

2. Dhanya Raveendranathan et.al 'Gender-specific correlates of Alcohol use among college students in Kerala, India. Indian journal of Psychological Medicine, Vol.42, Issue 4, July 2020.

3. Hemalatha B D. "Footprints of Educational Technology in Higher Education". International Research Journal on Advanced Science Hub, 3, Special Issue ICITCA-2021 5S, 2021, 21-26

4. $\quad$ Akash I; Ashok R; Harshini R; Prabakar D; Sangeetha K. "Students Overall Performance Application". International Research Journal on Advanced Science Hub, 3, Special Issue ICARD-2021 3S, 2021, 116-119. doi: 10.47392/irjash.2021.077

5. Sona Thakur; Kuldip Kaur Grewal. "A Study of Self-Concept among Adolescents". International Research Journal on Advanced Science Hub, 2, Special Issue ICSTM 12S, 2020, 68-72. doi: 10.47392/irjash.2020.263

6. Nichols, M et.al (2012) What is the optimal level of population alcohol consumption for chronic disease prevention in England? Modeling the impact of changes in average consumption levels. BMJ Open, 2,1-8.

7. Sacks, J et.al.(2013) State costs of excessive alcohol consumption, 2006. American Journal of Preventive Medicine, 45, 474-485

8. White, A., \& Hingson. R (2014) The burden of alcohol use: Excessive alcohol consumption and related consequences among college students. Alcohol Research: Current Reviews, 35, 201-218.

9. $\quad$ www.niaaa.nih.gov/publications

10. www.deccanchronical.com/nation/currentaffairs/220418/ban-drunk-students-in colleges-madras-high-court.htm 